\title{
Levels of messenger RNA encoding ovarian receptors for FSH and LH in cattle during superovulation with equine chorionic gonadotrophin versus $\mathrm{FSH}$
}

\author{
K Soumano, J G Lussier and C A Price \\ Centre de Recherche en Reproduction Animale, Faculté de Médecine Vétérinaire, Université de Montréal, CP 5000, St-Hyacinthe, Québec J2S 7C6, Canada \\ (Requests for offprints should be addressed to C A Price)
}

\begin{abstract}
This study tested the hypothesis that luteal LH receptor (LHr) and follicular LHr and FSH receptor (FSHr) steadystate mRNA levels are greater during superovulation with equine chorionic gonadotrophin (eCG) compared with that with FSH. Heifers were stimulated with eCG $(n=10)$ or FSH $(n=10)$, and ovaries were recovered the day before and at 12 and $24 \mathrm{~h}$ after luteolysis was induced with prostaglandin $\mathrm{F}_{2 \alpha}\left(\mathrm{PGF}_{2 \alpha}\right)$. Total RNA was purified from individual follicles and corpora lutea. Steady-state levels of LHr and FSHr mRNA were assessed by slot blot analysis employing homologous cDNA probes. There were no differences in luteal LHr between FSH- and eCGstimulated animals before luteolysis, and hybridization signals were detected in only one of six animals by $12 \mathrm{~h}$
\end{abstract}

after injection of $\mathrm{PGF}_{2 \alpha}$. After $\mathrm{PGF}_{2 \alpha}$ injection, steadystate levels of follicular LHr were 4-fold lower $(P<0.05)$ and follicular FSHr mRNA levels were 2.4-fold lower $(P<0 \cdot 05)$ in eCG- compared with FSH-treated cattle. In eCG-treated animals, induction of luteolysis led to a significant increase in follicular LHr mRNA levels $(P<0 \cdot 01)$ and a significant decrease in follicular $\mathrm{FSHr}$ mRNA levels $(P<0 \cdot 01)$. There was no such effect of luteolysis in FSH-treated animals. We conclude that superovulation with eCG, compared with FSH, results in lower follicular levels of LHr and FSHr mRNA but does not affect luteal LHr mRNA levels.

Journal of Endocrinology (1998) 156, 373-378

\section{Introduction}

In cattle, plasma concentrations of progesterone and oestradiol are higher during superovulation with equine chorionic gonadotrophin (eCG) than with follicle-stimulating hormone (FSH) preparations low in luteinizing hormone (LH) bioactivity (Armstrong et al. 1983, Driancourt \& Fry 1992, Ben Jebara et al. 1994). In cattle, steroid biosynthesis is under the control of LH in luteal cells (Niswender \& Nett 1994) and both LH and FSH in follicular cells (Gore-Langton \& Armstrong 1994). These glycoprotein hormones act through specific receptors; once bound with ligand, the hormone-receptor complex activates the adenylate cyclase pathway (Marsh \& LeMaire 1974, Davis 1994, Hillier et al. 1994, Laurent-Cadoret \& Guillou 1995) leading to stimulation of the steroidogenic pathway. The first step in gonadotrophin-stimulated steroidogenesis is the transfer of cholesterol from the outer to the inner mitochondrial membrane, where it is converted to pregnenolone by cytochrome P450 cholesterol side-chain cleavage $\left(\mathrm{P}^{4} 50_{\text {scc }}\right)$ (reviewed by Miller 1988, Niswender \& Nett 1994, Niswender et al. 1994). This transport may be mediated by several factors (reviewed by Hall \& Almahbobi 1992, Jefcoate et al. 1992), of which steroidogenic acute regulatory (StAR) protein is believed to be the rate-limiting step for steroidogenesis (Hartung et al. 1995, Stocco \& Clark 1996, Stocco 1997). Pregnenolone is converted to progesterone by $3 \beta$-hydroxysteroid dehydrogenase $(3 \beta-\mathrm{HSD})$ in corpora lutea $(\mathrm{CL})$ and in follicles (reviewed by Labrie et al. 1992), or to androgens and subsequently to oestradiol in follicles (Fortune 1986, Miller 1988).

We have recently shown that ovarian hyperstimulation with eCG increases, compared with stimulation with FSH, levels of mRNA for follicular, but not luteal, StAR protein (Pescador et al. 1996, Soumano \& Price 1997). This may be specific to theca cells, because StAR protein is weakly expressed in non-luteinized bovine granulosa cells (Soumano \& Price 1997), and follicular cytochrome P450 $17 \alpha$-hydroxylase $\left(\mathrm{P}^{4} 50_{17 \alpha}\right) \mathrm{mRNA}$ levels were increased in eCG- compared with FSH-stimulated cows (Soumano et al. 1996). The expression of StAR protein is acutely regulated by LH (Clark et al. 1995, Juengel et al. 1995), thus modifications of StAR protein mRNA levels may reflect changes in the LH signal to the cell, which may also involve LH receptor number and receptor synthesis.

It has been shown that gonadotrophin regulation of bovine (Houde et al. 1994) and rat ovarian FSH receptor 
(FSHr) (LaPolt et al. 1992) and LH receptor (LHr) (LaPolt et al. 1990, 1991, Nakamura et al. 1990, Segaloff et al. 1990) content during follicular growth, ovulation and luteinization is associated with similar changes in their respective receptor message levels. For instance, induction of follicular growth in rats with eCG increased ovarian LHr and FSHr numbers and mRNA content (LaPolt et al. 1990, 1992), and FSH caused a dose-dependent increase in FSHr mRNA content in cultured rat granulosa cells (Tilly et al. 1992).

The aim of this study was to test the hypothesis that, during superovulation, the higher LH activity of eCG, compared with a commercial FSH preparation (Folltropin), stimulates an increase in steady-state levels of mRNA for $\mathrm{LH}$ receptors in luteal cells as well as mRNA for LH and FSH receptors in follicular cells.

\section{Material and Methods}

\section{Animals and treatments}

The study was conducted on twenty, 18-month-old crossbred Holstein-Friesian heifers as previously described (Soumano et al. 1996). Animals were housed indoors at the CRRA farm in St-Hyacinthe, Québec, Canada (lat $45^{\circ} 30^{\prime} \mathrm{N}$ ), and were maintained under standard husbandry conditions. Observation for oestrus was conducted daily to verify that the animals were displaying regular oestrous cycles before the beginning of the treatments. The animals were divided into two groups ( $n=10 /$ group) for super-ovulation with either eCG or FSH. The treatments began on day 9 of the cycle (day $0=$ day of oestrus). The eCG-treated animals received one i.m. injection of $2500 \mathrm{IU}$ Folligon (Intervet Canada Inc., West Hill, ON, Canada). The FSH-treated group received, at 12-h intervals, eight i.m. injections of $2 \cdot 25 \mathrm{mg}$ Folltropin-V (Vetrepharm Inc., London, ON, Canada; equivalent to $50 \mathrm{mg}$ NIH-FSH-P1). On the morning of day 12, animals received an i.m. injection of $500 \mu \mathrm{g}$ prostaglandin $\mathrm{F}_{2 \alpha}\left(\mathrm{PGF}_{2 \alpha}\right.$ : Cloprostenol; Estrumate, Cooper Agropharm Inc., Ajax, ON, Canada) to induce luteal regression.

Plasma progesterone and oestradiol concentrations have been reported for these treatments in these animals in a previous superovulatory cycle (Soumano et al. 1996).

\section{RNA extraction}

Ovaries were removed from hyperstimulated heifers by colpotomy on day 11 or 12 (before $\mathrm{PGF}_{2 \alpha}, n=4$ heifers/ treatment), and at $12 \mathrm{~h}(n=3$ heifers/treatment) and $24 \mathrm{~h}$ $\left(n=3\right.$ heifers/treatment) after $\mathrm{PGF}_{2 \alpha}$ injection. CL and all follicles greater than $3 \mathrm{~mm}$ were removed within $30 \mathrm{~min}$ of ovariectomy, and were placed in denaturing solution (4 M guanidine isothiocyanate, $0.12 \mathrm{M} \beta$ mercaptoethanol and $20 \mathrm{mM}$ sodium acetate, $\mathrm{pH} 6 \cdot 0$ ) and stored at $-70{ }^{\circ} \mathrm{C}$ until total RNA was extracted.
The thawed tissues were homogenized in denaturing solution, and total RNA was isolated by centrifugation for $21 \mathrm{~h}$ at $174000 \mathrm{~g}$ on a cushion of $5 \cdot 7 \mathrm{M}$ caesium chloride as described by Davis et al. (1986). The pellet was resuspended in $3 \mathrm{M}$ sodium acetate, $\mathrm{pH} 5 \cdot 2$, precipitated twice with ethanol and quantified by spectrophotometry at $260 \mathrm{~nm}$. Total RNA was analyzed by slot blot hybridization $(6 \mu \mathrm{g})$ as previously described (Sambrook et al. 1989). One slot blot contained all CL samples whereas follicular samples were distributed across four blots. Membranes were then cross-linked $(150 \mathrm{~mJ})$ in a UV chamber (Bio Rad, Mississauga, ON, Canada) and incubated for $2 \mathrm{~h}$ in prehybridization solution, containing $10 \%$ dextran sulphate, $5 \times$ saline-sodium phosphate-EDTA (SSPE: $0.75 \mathrm{M} \mathrm{NaCl}, 50 \mathrm{mM} \mathrm{NaH} \mathrm{PO}_{4} \cdot \mathrm{H}_{2} \mathrm{O}, 5 \mathrm{mM}$ EDTA, $\mathrm{pH} 7 \cdot 4), 5 \times$ Denhardt's solution $(0 \cdot 1 \%$ Ficoll, $0 \cdot 1 \%$ polyvinylpyrrolidone and $0 \cdot 1 \%$ bovine serum albumin), $0 \cdot 5 \%$ sodium dodecyl sulphate (SDS), and herring sperm DNA $(200 \mathrm{mg} / \mathrm{ml})$ (Sambrook et al. 1989). The CL samples were hybridized with labelled bovine LHr cDNA probe while blots containing follicular samples were sequentially hybridized with labelled bovine $\mathrm{LHr}$ and $\mathrm{FSHr}$ cDNA probes. Hybridization was performed overnight at $65^{\circ} \mathrm{C}$. After hybridization, membranes were washed in $2 \times$ SSPE $-0 \cdot 1 \%$ SDS twice at room temperature, and twice at $65{ }^{\circ} \mathrm{C}$. Membranes were then stripped and rehybridized to a human $28 \mathrm{~S}$ ribosomal RNA (rRNA) probe for the standardization of RNA loading. The labelled membranes were exposed to Kodak X-Omat film at $-70{ }^{\circ} \mathrm{C}$ in the presence of an intensifying screen. Autoradiograms were scanned with a densitometer (Collage Analysis; Fotodyne Inc., Hartland, WI, USA) after 1 to 5 days exposure.

\section{cDNA probes}

The bovine LHr cDNA probe was generated by reverse transcription and polymerase chain reaction (RT-PCR). The probe used corresponds to a $786 \mathrm{bp}$ cDNA fragment of the amino terminal extracellular binding domain (from exon 11) up to the seventh transmembrane spanning segment (nucleic acids 1087 to 1899 of the genebank sequence deposited by Lussier et al. 1995). The bovine FSHr cDNA probe was a $1264 \mathrm{bp}$ fragment generated by RT-PCR and representing a portion of the extracellular binding domain to the $3^{\prime}$ stop codon (Houde et al. 1994). The $28 \mathrm{~S}$ rRNA probe was a $1.4 \mathrm{~kb}$ portion from an internal region of the human gene (Gonzalez et al. 1985). All probes were labelled with $\left[\alpha-{ }^{32} \mathrm{P}\right] \mathrm{dCTP}$, to a specific activity of $1.5-3.0 \times 10^{9}$ d.p.m. $/ \mu \mathrm{g}$, by random primer extension using a kit (Boehringer Mannheim, Laval, PQ, Canada). Labelled probes were separated from unincorporated $\left[{ }^{32} \mathrm{P}\right] \mathrm{dCTP}$ by centrifugation through a minicolumn using Wizard PCR Preps DNA purification system (Promega, Montreal, PQ, Canada). 


\section{Statistical analysis}

The density of hybridization signals was corrected for loading efficiency using hybridization to $28 \mathrm{~S} \mathrm{rRNA}$, and for follicular samples, these corrected data were normalized relative to a follicular quality control sample (pooled RNA from bovine follicles) that was included in all four slot blots (coefficient of variation of the quality control sample between blots was <20\%). Follicles were classified by size into small (3-6 mm), medium $(6-9 \mathrm{~mm})$ and large $(>9 \mathrm{~mm})$ and the mean steady-state levels of each RNA within follicle size group were calculated (in dimensionless units) for each animal. As the data did not follow a normal distribution by the Shapiro-Wilk test, they were transformed to common logarithms, and analysis of variance (ANOVA) was used to test effects of time relative to $\mathrm{PGF}_{2 \alpha}$ injection, gonadotrophin treatment and time by treatment interaction. Additionally, for follicular samples, the effect of follicle size was assessed. Comparisons between individual groups were made with the TukeyKramer HSD test. Analyses were performed with JMP software (SAS Institute, Cary, NC, USA). The data are presented as arithmetic mean ( \pm s.E.M.) mRNA levels relative to $28 \mathrm{~S}$ rRNA.

\section{Results}

\section{Luteal $m R N A$ levels}

There was a significant main effect of time but not of treatment on steady-state luteal LHr mRNA levels $(P<0 \cdot 05)$. Before luteolysis, LHr mRNA levels were not significantly different between FSH $(11 \cdot 0 \pm 3 \cdot 8$ relative units) and eCG $(623.6 \pm 614 \cdot 0$ relative units $)$ treated animals $(P>0 \cdot 05)$; the apparently large value for the eCG group was caused by one animal showing an extremely high level of LHr mRNA. Levels of mRNA for $\mathrm{LHr}$ decreased significantly $(P<0 \cdot 001)$ after $\mathrm{PGF}_{2 \alpha}$ injection, such that at $12 \mathrm{~h}$ after $\mathrm{PGF}_{2 \alpha}$ injection only one eCGtreated animal showed a detectable hybridization signal (1.4 relative units), and no animals showed detectable signals at $24 \mathrm{~h}$ after $\mathrm{PGF}_{2 \alpha}$.

\section{Follicular $m R N A$ levels}

There were no effects of follicle size or interactions between follicle size and time or treatment on steady-state levels of mRNA for $\mathrm{LHr}$ or FSHr in follicles (illustrated for $24 \mathrm{~h}$ after $\mathrm{PGF}_{2 \alpha}$ in Fig. 1). Consequently, all further analyses were performed with the mean value of all follicles (irrespective of size).

There was a significant main effect of treatment $(P<0 \cdot 05)$ on levels of mRNA for $\mathrm{LHr}$, these being 3- to 5-fold lower overall in eCG- compared with FSHstimulated animals (Fig. 2). However, an effect of treatment at each time point did not reach significance, owing

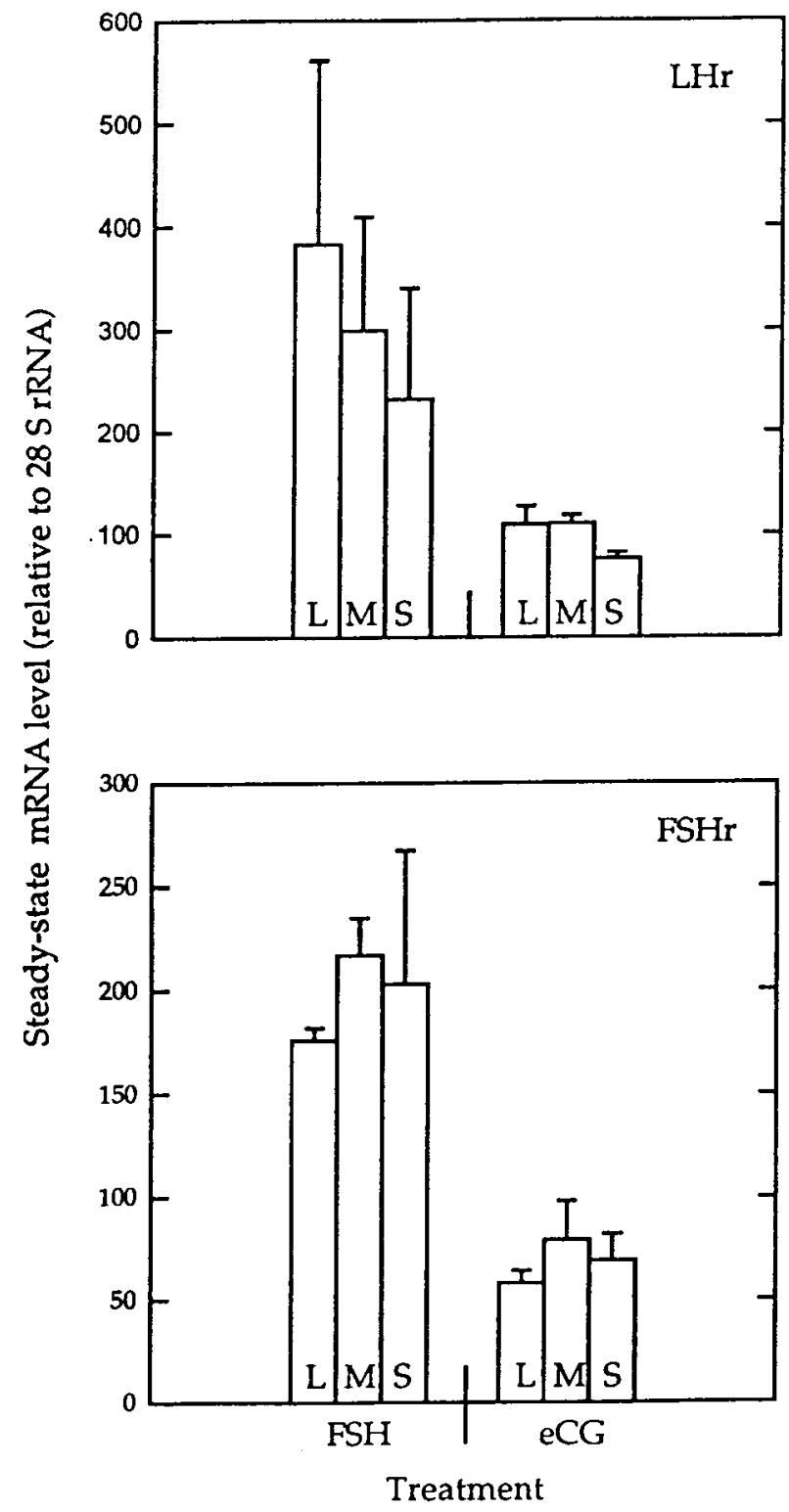

Figure 1 Steady-state mRNA levels (relative to $28 \mathrm{~S}$ rRNA) of $\mathrm{LHr}$ and $\mathrm{FSHr}$ in large $(\mathrm{L} ;>9 \mathrm{~mm})$, medium $(\mathrm{M} ; 6-9 \mathrm{~mm})$ and small $(\mathrm{S}$; 3-6 mm) follicles from cattle undergoing ovarian hyperstimulation with FSH or eCG. These data, which serve to illustrate the similarity across follicle size groups within treatment, are for $24 \mathrm{~h}$ after luteolysis was induced by injection with prostaglandin $F_{2 \alpha}$. Each bar represents the mean of three cows except the mean for small follicles from the eCG-treated group, in which two cows contributed follicles.

in part to the large variation among the FSH-treated animals. For eCG-stimulated cows, LHr mRNA levels increased with time, and were $2 \cdot 4$-fold higher at $24 \mathrm{~h}$ after, compared with before, $\mathrm{PGF}_{2 \alpha}$ injection $(P<0 \cdot 01$; Fig. 2). No such effects of time were observed between 


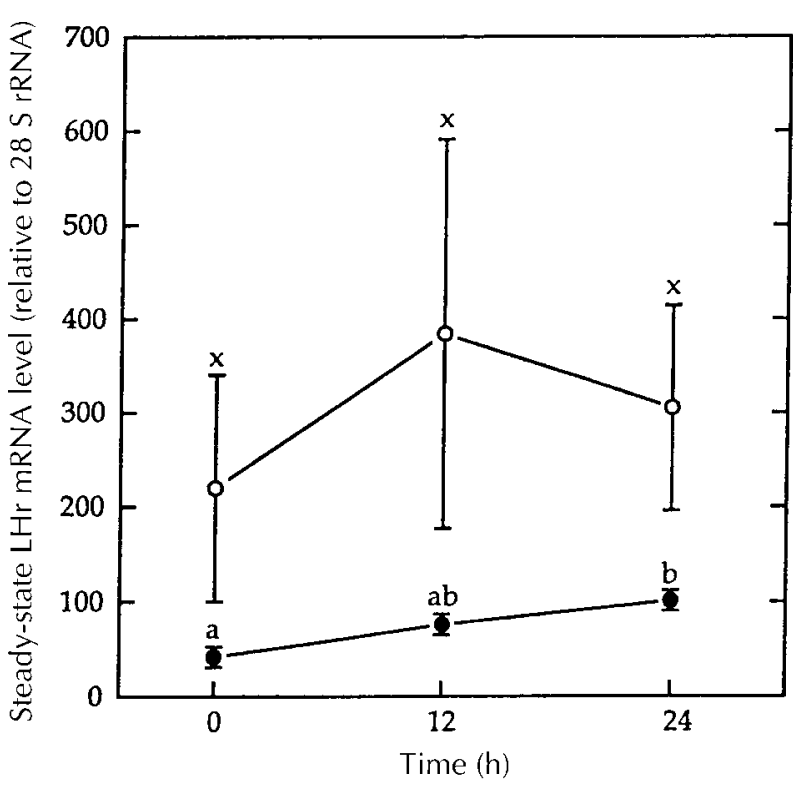

Figure 2 Effect of treatment and of time relative to prostaglandin $F_{2 a}$ injection on steady-state levels of LHr mRNA (relative to $28 \mathrm{~S}$ rRNA) in follicles from cattle undergoing superovulation with FSH $(\bigcirc)$ and eCG $(\bullet)$. Within treatments, different letters denote significant differences $(P<0 \cdot 05)$. The main effect of treatment was significant $(P<0 \cdot 05) . n=4$ at $0 \mathrm{~h}$, and $n=3$ at 12 and at $24 \mathrm{~h}$.

follicles collected before and after $\mathrm{PGF}_{2 \alpha}$ injection in FSH-treated heifers $(P<0 \cdot 05$; Fig. 2).

There was a significant main effect of treatment and a time-by-treatment interaction for levels of mRNA encoding FSHr $(P<0 \cdot 05)$. There was a significant effect of time relative to $\mathrm{PGF}_{2 \alpha}$ injection on levels of mRNA for FSHr in eCG-treated heifers, such that levels after the induction of luteolysis decreased to $58 \%$ of the levels observed before luteolysis $(P<0 \cdot 01$; Fig. 3). There was no significant effect of time on FSHr mRNA levels in FSH-stimulated cattle. At 12 and $24 \mathrm{~h}$ after luteolysis, the relative levels of FSHr mRNA in follicles from FSH-treated animals were two to three times higher than those in follicles from eCG-treated animals $(P<0 \cdot 05$; Fig. 3$)$.

\section{Discussion}

The aim of this study was to test the hypothesis that, during superovulation, the higher LH activity of eCG, compared with a commercial FSH preparation (Folltropin), stimulates an increase in steady-state levels of mRNA for LH receptors in luteal cells as well as mRNA for LH and FSH receptors in follicular cells. The main observations from this study are that: (1) there were no significant differences between eCG and FSH treatments on the levels of LHr mRNA in CL and (2) after $\mathrm{PGF}_{2 \alpha}$ injection, superovulation with eCG, compared with FSH, resulted in a lower level of follicular LH and FSH receptor mRNA.

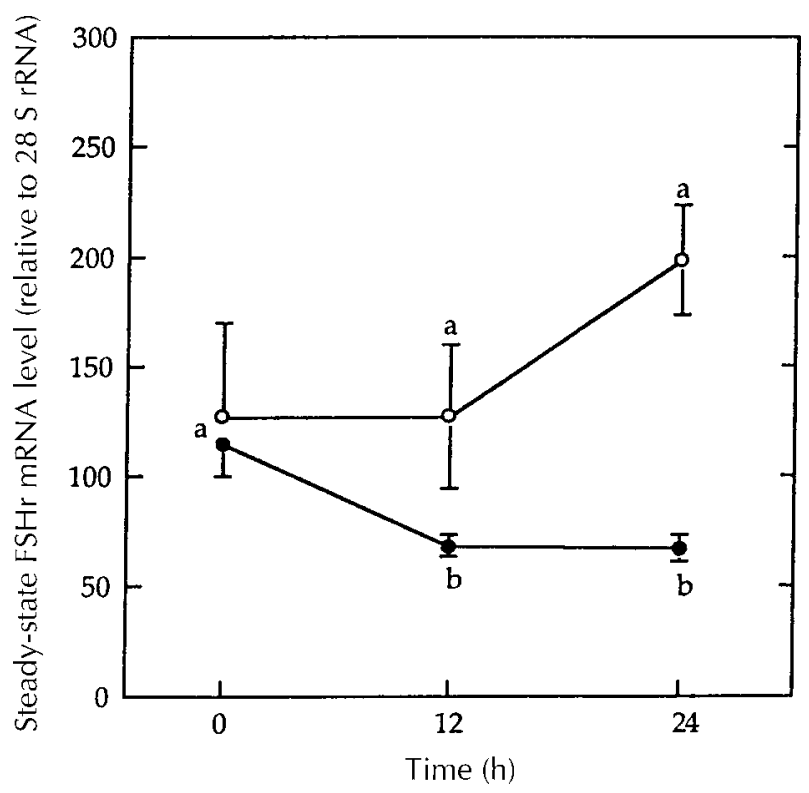

Figure 3 Effect of treatment and of time relative to prostaglandin

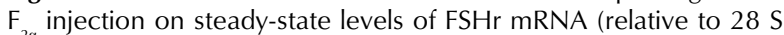
rRNA) in follicles from cattle undergoing superovulation with FSH $(\bigcirc)$ and eCG $(\bullet)$. Different letters denote significant differences $(P<0 \cdot 05)$ across times and treatments. $n=4$ at $0 \mathrm{~h}$, and $n=3$ at 12 and at $24 \mathrm{~h}$.

The lack of a treatment difference in LHr mRNA in $\mathrm{CL}$ is perplexing. The obvious endocrine effect of eCGinduced superovulation, compared with saline or FSH, is increased plasma progesterone concentrations, most noticeable before luteolysis (Ben Jebara at al. 1994, Soumano \& Price 1997). However, this is not accompanied by changes in levels of mRNA encoding luteal $\mathrm{LHr}$ (present study), StAR protein or $\mathrm{P} 450_{\mathrm{scc}}$ (Pescador et al. 1996), or 3ß-HSD (K Soumano \& C A Price, unpublished observations). Collectively, these data suggest that increased plasma concentrations of progesterone are a result of an LH-dependent mechanism downstream of mRNA (e.g. protein stability and/or enzyme activity; Belfiore et al. 1994). An alternative explanation is that increased progesterone concentrations are of follicular origin. Some evidence from the literature supports this idea. Treatment with eCG, compared with FSH, led to greater intrafollicular progesterone secretion in goats in vivo (Kumar et al. 1992) and in short-term culture in sheep (Driancourt \& Fry 1992). However, in the present study, there were no treatment effects on follicular LHr (or FSHr) mRNA levels before luteolysis, and we have shown that follicular StAR protein, $\mathrm{P} 450_{\mathrm{scc}}$ and $3 \beta-\mathrm{HSD}$ mRNA levels are not different between these two treatments before luteolysis (Soumano et al. 1996, Soumano \& Price 1997). So again, the increase in progesterone concentrations at this time is most likely effected downstream of steady-state mRNA levels. 
Plasma oestradiol concentrations following luteolysis are significantly higher in animals stimulated with eCG compared with those stimulated with FSH (Ben Jebara et al. 1994, Soumano et al. 1996). The present data now show that follicular gonadotrophin receptor mRNAs are lower in eCG-stimulated compared with FSH-stimulated animals after luteolysis, coincident with increases in follicular StAR protein and $\mathrm{P} 450_{17 \alpha}$ mRNA levels (Soumano et al. 1996, Soumano \& Price 1997). As StAR protein is acutely regulated by LH (Stocco 1997), the increased level of StAR protein mRNA suggests increased stimulation by eCG even though receptor mRNA levels are reduced.

The lower steady-state FSHr and LHr mRNA levels during eCG compared with FSH treatment suggest either down-regulation of these receptors during eCG treatment (Hoffman et al. 1991), or up-regulation during FSH treatment. Low doses of FSH and eCG have been shown to increase $\mathrm{FSH}$ and $\mathrm{LH}$ binding sites and $\mathrm{FSHr}$ and $\mathrm{LHr}$ mRNA levels in rats and mice (LaPolt et al. 1990, 1992, Segaloff et al. 1990, Tilly et al. 1992, Wang \& Greenwald 1993a,b), although low and high levels of FSH decreased FSHr mRNA levels in bovine granulosa cells in vitro (Houde et al. 1994). Down-regulation of $\mathrm{FSHr}$ and $\mathrm{LHr}$ mRNA is usually only observed with high (ovulatory) levels of eCG or hCG (LaPolt et al. 1990, 1992, Segaloff et al. 1990). Thus it is possible that the eCG dose regimen used to superovulate cattle is high enough to cause down-regulation of LHr and FSHr mRNA levels. This may be supported by the increased incidence of luteinization observed in cattle undergoing superovulation with eCG (Boland et al. 1991).

Interestingly, eCG had an opposing effect on LHr and FSHr mRNA levels; FSHr mRNA decreased with time after the induction of luteolysis, whereas LHr mRNA levels increased with time. This may be related to the relative FSH:LH activities of eCG in cattle; although eCG binds to both receptors, the predominant activity is that of FSH (Murphy \& Martinuk 1991), so it may bind to FSHr to a greater extent than to LHr. In this case, downregulation of FSHr with a concomitant up-regulation of LHr may occur.

The induction of luteolysis caused a marked decrease in luteal LHr mRNA levels. This decrease is coincident with that observed for StAR protein mRNA (Pescador et al. 1996), and supports an acute response of StAR protein to the loss of $\mathrm{LH}$ receptors, and to the uncoupling of the receptor from the cAMP second messenger cascade reported during this time in bovine CL (Pate \& Condon 1984). The induction of luteolysis also resulted in an increase in follicular LHr mRNA and a decrease in FSHr mRNA levels in eCG-stimulated cattle. This phenomenon can probably be interpreted as reflection of the normal physiological process of luteinization. A higher incidence of follicle luteinization has been observed in eCG-stimulated than in Folltropin-stimulated cattle (Boland et al. 1991). During the luteinization process, bovine follicular cells lose their ability to express $\mathrm{FSHr}$ (Houde et al. 1994, Rajapaksha et al. 1996) while developing LHr needed for LH-dependent progesterone synthesis (Niswender \& Nett 1994).

In summary, this study has demonstrated that, during superovulation of cattle, stimulation with eCG compared with FSH results in lower steady-state mRNA levels for FSHr and LHr in follicles. Treatment with eCG resulted in an increase in LHr mRNA and a decrease in FSHr mRNA levels following the induction of luteolysis. There were no differences between these superovulatory treatments in their effects on luteal LHr mRNA levels.

\section{Acknowledgements}

We are grateful to Dr D Vaillancourt for performing the ovariectomies. We thank Greg Shewfelt, Vetrepharm Research Inc., for the gift of Folltropin, and Marie-Josée Neault, Intervet Canada, for the gift of Folligon. This work was funded by NSERC and MESS.

\section{References}

Armstrong DT, Pfitzner AP, Warnes GM, Ralph MM \& Seamark RF 1983 Endocrine responses of goats after induction of superovulation with PMSG and FSH. Journal of Reproduction and Fertility 67 395-401.

Belfiore CJ, Hawkins DE, Wiltbank MC \& Niswender GD 1994 Regulation of cytochrome P450 scc synthesis and activity in the ovine corpus luteum. Journal of Steroid Biochemistry and Molecular Biology 51 283-290.

Ben Jebara MK, Carrière PD \& Price CA 1994 Decreased pulsatile LH secretion in heifers superovulated with eCG or FSH. Theriogenology 42 685-694.

Boland MP, Goulding D \& Roche JF 1991 Alternative gonadotrophins for superovulation in cattle. Theriogenology 35 5-17.

Clark BJ, Soo S-C, Caron KM, Ikeda Y, Parker KL \& Stocco DM 1995 Hormonal and developmental regulation of the steroidogenic acute regulatory protein. Molecular Endocrinology 9 1346-1355.

Davis JS 1994 Mechanisms of hormone action: luteinizing hormone receptors and second-messenger pathways. Current Opinion in Obstetrics and Gynecology 6 254-261.

Davis LG, Dibner MD \& Battey JF 1986 Basic Methods in Molecular Biology. New York: Elsevier Science Publishing Co., Inc.

Driancourt MA \& Fry RC 1992 Effect of superovulation with pFSH or PMSG on growth and maturation of the ovulatory follicles in sheep. Animal Reproduction and Science 27 279-292.

Fortune JE 1986 Bovine theca and granulosa cells interact to promote androgen production. Biology of Reproduction 35 292-299.

Gonzalez IL, Gorski JL, Campen TJ, Dorney DJ, Erickson JM, Sylvester JE \& Schmickel RD 1985 Variation among human 28S ribosomal RNA genes. Proceedings of the National Academy of Sciences of the USA 82 7666-7670.

Gore-Langton RE \& Armstrong DT 1994 Follicular steroidogenesis and its control. In The Physiology of Reproduction, vol 1, pp 571-628. Eds E Knobil \& JD Neill. New York: Raven Press.

Hall PF \& Almahbobi G 1992 The role of the cytoskeleton in the regulation of steroidogenesis. Journal of Steroid Biochemistry and Molecular Biology 43 769-777.

Hartung S, Rust R, Balvers M \& Ivell R 1995 Molecular cloning and in vivo expression of the bovine steroidogenic acute regulatory protein. Biochemical and Biophysical Research Communications 215 646-653 
Hillier SG, Whitelaw PF \& Smyth CD 1994 Follicular oestrogen synthesis: the 'two-cell, two-gonadotropin' model revisited. Molecular and Cellular Endocrinology 100 51-54.

Hoffman YM, Peegel H, Sprock MJE, Zhang QY \& Menon KMJ 1991 Evidence that human chorionic gonadotropin/luteinizing hormone receptor down-regulation involves decreased levels of receptor messenger ribonucleic acid. Endocrinology $\mathbf{1 2 8}$ 388-393.

Houde A, Lambert A, Saumande J, Silversides DW \& Lussier JG 1994 Structure of bovine follicle-stimulating hormone receptor complementary DNA and expression in bovine tissues. Molecular Reproduction and Development 39 127-135.

Jefcoate CR, McNamara BC, Artemenko I \& Yamazaki T 1992 Regulation of cholesterol movement to mitochondrial cytochrome P450 scc in steroid hormone synthesis. Journal of Steroid Biochemistry and Molecular Biology 43 751-767.

Juengel JL, Meberg BM, Turzillo AM, Nett TM, Niswender GD 1995 Hormonal regulation of messenger ribonucleic acid encoding steroidogenic acute regulatory protein in ovine corpora lutea. Endocrinology 136 5423-5429.

Kumar J, Osborn JC, Cameron AW \& Trounson AO 1992 Follicular steroidogenesis and oocyte maturation after superovulation of goats (Capra hircus) with gonadotrophins. Journal of Reproduction and Fertility 95 371-383.

Labrie F, Simard J, Luu-The V, Belanger A \& Pelletier G 1992 Structure, function and tissue-specific gene expression of $3 \beta$-hydroxysteroid dehydrogenase/5-ene-4-ene isomerase enzymes in classical and peripheral intracrine steroidogenic tissues. Journal of Steroid Biochemistry and Molecular Biology 43 805-826.

Laurent-Cadoret V \& Guillou F 1995 Mécanismes moléculaires de stimulation et désensibilisation de la cellule de Sertoli par l'hormone folliculo-stimulante. Reproduction, Nutrition, Development 35 213-235.

LaPolt PS, Oikawa M, Jia X-C, Dargan C \& Hsueh AJW 1990 Gonadotropin-induced up- and down-regulation of rat ovarian LH receptor message levels during follicular growth, ovulation and luteinization. Endocrinology 126 3277-3279.

LaPolt PS, Jia X-C, Sincich C \& Hsueh AJW 1991 Ligand-induced down-regulation of testicular and ovarian luteinizing hormone (LH) receptors is preceded by tissue-specific inhibition of alternatively processed LH receptor transcripts. Molecular Endocrinology $\mathbf{5}$ 397-403.

LaPolt PS, Tilly JL, Aihara T, Nishimori K \& Hsueh AJW 1992 Gonadotropin-induced up- and down-regulation of ovarian FSH receptor gene expression: effects of PMSG, hCG and recombinant FSH. Endocrinology 130 1289-1295.

Lussier JG, Houde A, Ethier J \& Silversides DW 1995 Complementary DNA structure of the bovine LH receptor. GenBank accession number U 20504.

Marsh JM \& LeMaire WJ 1974 The role of cyclic AMP and prostaglandins in the action of luteinizing hormone. In Gonadotropins and Gonadal Function, pp 376-390. Ed NR Mondgal. New York: Academic Press.

Miller WL 1988 Molecular biology of steroid hormone synthesis. Endocrine Reviews 9 295-318.

Murphy BD \& Martinuk SD 1991 Equine chorionic gonadotropin. Endocrine Reviews 12 27-44.
Nakamura K, Minegish T, Takakura Y, Miyamoto K, Hasegawa Y, Ibuki Y \& Igarashi M 1990 Regulation of LH/hCG receptor by gonadotropins in rat ovary. Biochemical and Biophysical Research Communications 172 786-792.

Niswender GD \& Nett TM 1994. The corpus luteum and its control in infraprimate species. In The Physiology of Reproduction, vol 1, chap 14, pp 781-816. Eds E Knobil \& JD Neill. New York: Raven Press.

Niswender GD, Juengel JL, McGuire WJ, Belfiore CJ \& Wiltbank MC 1994 Luteal function: the estrous cycle and early Pregnancy. Biology of Reproduction 50 239-247.

Pate JL \& Condon WA 1984 Effects of the prostaglandin $\mathrm{F}_{2 \alpha}$ on agonist-induced progesterone production in cultured bovine luteal cells. Biology of Reproduction 31 427-435.

Pescador N, Soumano K, Stocco DM, Price CA \& Murphy BD 1996 Steroidogenic acute regulatory protein during the bovine luteal phase. Biology of Reproduction 55 485-491.

Rajapaksha WR, Robertson L \& O'Shaughnessy PJ 1996 Expression of follicle-stimulating hormone-receptor mRNA alternate transcripts in bovine granulosa cells during luteinization in vivo and in vitro. Molecular and Cellular Endocrinology 120 25-30.

Sambrook J, Fritsch EF \& Maniatis T 1989 Molecular Cloning: A Laboratory Manual, edn 2. New York: Cold Spring Harbor Laboratory Press.

Segaloff DL, Wang H \& Richards JS 1990 Hormonal regulation of luteinizing hormone/chorionic gonadotropin receptor mRNA in rat ovarian cells during follicular development and luteinization. Molecular Endocrinology 4 1856-1865.

Soumano K \& Price CA 1997 Ovarian follicular steroidogenic acute regulatory protein, low-density lipoprotein receptor and cytochrome P450 side-chain cleavage messenger ribonucleic acids in cattle undergoing superovulation. Biology of Reproduction 56 516-522.

Soumano K, Silversides DW, Doizé F \& Price CA 1996 Follicular $3 \beta$-hydroxysteroid dehydrogenase and cytochromes $\mathrm{P} 450$ $17 \alpha$-hydroxylase and aromatase messenger ribonucleic acids in cattle undergoing superovulation. Biology of Reproduction 55 1419-1426.

Stocco DM 1997 A StAR search: implications in controlling steroidogenesis. Biology of Reproduction 56 328-336.

Stocco DM \& Clark BJ 1996 Regulation of the acute production of steroids in steroidogenic cells. Endocrine Reviews 17 221-244.

Tilly JL, LaPolt PS \& Hsueh AJW 1992 Hormonal regulation of follicle-stimulating hormone receptor messenger ribonucleic acid levels in cultured rat granulosa cells. Endocrinology 130 1296-1302.

Wang XN \& Greenwald GS 1993a Synergistic effects of steroids with FSH on folliculogenesis, steroidogenesis and FSH- and hCGreceptors in hypophysectomized mice. Journal of Reproduction and Fertility 99 403-413.

Wang XN \& Greenwald GS 1993b Hypophysectomy of the cyclic mouse. II. Effects of follicle-stimulating hormone (FSH) and luteinizing hormone on folliculogenesis, FSH and human chorionic gonadotropin receptors, and steroidogenesis. Biology of Reproduction 48 595-605.

Received 26 March 1997

Revised manuscript received 7 August 1997

Accepted 24 September 1997 